Isabel Miguel*, Joaquim P. Valentim \& Felice Carugati

\title{
The degree of proximity in the construction of social representations: The case of intelligence
}

* Corresponding author: isabelmiguel@fpce.uc.pt

Article (Accepted version) (Refereed)

\section{Original citation:}

Miguel, I., Valentim, J. P., \& Carugati, F. (2012). The degree of proximity in the construction of social representations: The case of intelligence. Spanish Journal of Psychology, 15(3), 12441258.

doi: http://dx.doi.org/10.5209/rev_SJOP.2012.v15.n3.39411

This document is the author's final manuscript accepted version of the journal article, incorporating any revisions agreed during the peer review process. Some differences between this version and the published version may yet remain.

The final publication is available at: http://journals.cambridge.org/action/displayJournal?jid=SJP 


\title{
The degree of proximity in the construction of social representations: The case of intelligence
}

\author{
Isabel Miguel, Joquim P. Valentim, \& Felice Carugati
}

\begin{abstract}
The present article is devoted to the empirical endeavor of studying the effect of the degree of proximity, defined by specific socio-educational insertions, on the organization of social representations of intelligence. A questionnaire was answered by a sample of 752 participants belonging to five different social categories with different degrees of proximity and knowledge about intelligence: mothers, fathers, mother-teachers and non-parent students (psychology and science students). The questionnaire included different topics, namely concerning the concept of intelligence, its development and the effectiveness of teaching procedures. Results show that the principles organizing the contents of representations are linked to the personal involvement in intelligence, on which subjects more or less implied take different positions. Results produced suggest, therefore, that the content of representations is directly linked to the activation of social roles and the salience of the object, reflecting the functional character that the organization of representations has to specific social dynamics.
\end{abstract}

Key words: social representations, intelligence, degree of proximity 


\section{Introduction}

Social representations theory offers an alternative view to a number of notions traditionally employed in social psychology, such as attitudes (1993; Fishbein \& Ajzen, 1975; Petty, Fazio, \& Briñol, 2009) or beliefs (McGillicuddy-De Lisi \& Sigel, 1995; Sigel, 1985). The peculiarity of social representations in respect to other concepts in social psychology has been investigated in the literature (Carugati, 1990a, 1990b; Miguel, Valentim, \& Carugati, 2009). In general terms, the main and distinguishing feature of social representations is that they are first and foremost interested in the production of cultural meaning systems (Moscovici \& Marková, 2000) and, therefore, are taken as a molar concept which offers a broader theoretical schema for understanding the complex phenomena of production and reproduction of knowledge, capturing a more social, cultural and collective emphasis (Augoustinos, Walker, \& Donaghue, 2006; Howarth, 2006a; Voelklein \& Howarth, 2005). Additionally, social representations deal with the forms of common sense knowledge that are built and organized by individuals and groups during the daily routines of their lives (Jovchelovitch, 2008; Moscovici \& Hewstone, 1984). Based on the assertion that social representations are modes of thinking elaborated in the course of communication and shared by members of social groups (Moscovici, 1981), the theory is "conceived as capable of responding to the context and positioning of the person speaking" (Castro, 2006, p. 254), consequently relating social groups to social knowledge (Carugati, 1990b; Carugati \& Selleri, 2004). In this sense, social representations cannot be conceived as mere descriptions of contents of knowledge but rather as forms of socio-cognitive ruling, principles that generate positions in accordance with specific positions within a set of social relations and organize the symbolic processes that take place within these relations (Clémence, 2001; Doise, 1990, 1992; Doise, Clémence, \& Lorenzi-Cioldi, 1992). 
Considering the organizing principles of symbolic relations between individuals and groups, Doise (1993) has defined the theory as basically "a general theory about a metasystem of social regulations intervening in the system of cognitive functioning" (p. 157). Following Doise, Clémence and Lorenzi-Cioldi's (1992) model for the quantitative analysis of social representations, three aspects of social representations are to be studied: the organization of the representational field, the organizing principles of interindividual differences and their anchoring in related systems of symbolic meanings. Concerning the representational field, the interest is to explore the nature of shared aspects of representations, based on the assumption that there is a shared perception of a social object within a population. Organizing principles correspond to systematic variations in the weight individuals or groups give to different dimensions underlying the structure of the field of representation. The last element of the proposed model is anchoring, which leads to the consideration of how social position or social identities anchor people's representations (Doise, 1985, 1993). Doise (1992) has described three ways of analyzing social anchoring. The psychological analysis corresponds to general beliefs and values which define individual positioning. Psychosociological analysis of anchoring is linked to the way people perceive symbolic organization of positions, relations, and social categories. Lastly, the sociological analysis refers to the belonging of individuals to groups and to their shared social relations and experiences.

From this dynamic approach, Mugny and Carugati (1985) have shown, on their seminal work on social representations of intelligence and its development, that psychosocial variables such as the shortage of information regarding the object of representation, the (un)familiarity with that object, the necessity of decision making and the maintenance of a positive social identity organize representations of intelligence. This study is an interesting example of how different symbolic positions are anchored on specific socio-cognitive dynamics, which depend on the social positions that individuals occupy in the social space. More precisely, it has been shown that social identity steers the socio-cognitive management of the relative inexplicability 
of intelligence, leading specific representations to be produced by social categories for whom intelligence is a salient part of everyday experience and for whom it constitutes a significant part of their identity, namely parents and teachers. Further studies have provided empirical support to the fact that individuals are led to modulate the opinions they express in relation to intelligence when different group memberships are salient (Amaral, 1997; Poeschl, 1998, 2001; Räty \& Snellman, 1995; Räty, Snellman, \& Vornanen, 1993).

Additional evidence of this view is provided by some other studies, which show that the transformation of social representations are affected by several psychosocial factors such as personal involvement and distance to the object of representation. Whereas personal involvement can be conceived as a subjective and socially determined frame of reference that corresponds to an individual's relationship to a social object (Gruev-Vintila \& Rouquette, 2007), distance to the object is defined by specific practices, knowledge level and personal implication concerning the object of representation (Abric, 2001a). Additionally, research has also shown that representations develop in a process directly related to the level of knowledge available to the subjects (Lo Monaco \& Guimelli 2008), which can assume different degrees depending on its source of origin: description knowledge, direct experience with the object and knowledge acquired by limited or intensive practices with the object (Salesses, 2005a, 2005b). Altogether, research has shown how different psychosocial factors are important mechanisms generating variations in the content of the representation. These psychosocial factors are, therefore, considered major explaining variables in social thought, which help to explain how the activation of social dynamics linked to the varying degrees of proximity that the social object implies is found to modify the formation and structure of a representation (Carugati, Emiliani, \& Molinari, 1989; Carugati \& Selleri, 2004; Carugati, Selleri, \& Scappini, 1994; Dany \& Abric, 2007; Emiliani \& Molinari, 1994; Gurrieri, Wolter, \& Sorribas, 2007; Molinari \& Speltini, 1998). 
That structure is, therefore, related to the instrumentality of knowledge (Jovchelovitch, 2007), reflecting the fact that the organization of representations is functional for specific social dynamics. Bearing on this assertion, in this paper we intend to study the relevance of specific social dynamics capable of intervening and shaping different representational maps. For this reason, the degree of proximity - closer or more distant (Molinari \& Speltini, 1998) to the object of intelligence is explored. The degree of proximity was defined by the combination of two elements: direct experience with the object of intelligence and its affective salience. Direct experience is conceived as the more or less daily experience of differences of intelligence between individuals, which constitute a sort of "hard core" (Abric, 1997a, 2001a) around which various social representations of intelligence are constructed (Mugny \& Carugati, 1985). In terms of intelligence, the recognition of the differences is visible and immediately accessible to perception and, in the end, requires no analyzing. For example, no formal investigation would be needed to point up the enormous disparity in academic achievement: often pupils attending different schools, reputedly of different intellectual levels, will nevertheless achieve the same results; on the other hand, within the same school or class, the level of results varies a great deal from one pupil to another. Affective salience concerning the object is conceived in terms of personal involvement and responsibility towards the development of intelligence and decision making in educational matters, which may affect children's educational career. Drawing from their different social integrations, different subjects may experience more or less affective involvement towards intelligence, which may stem from the need to cope with diverse and possibly demanding requirements related to their educational role. In terms of representations of intelligence, distinct social groups are differently predisposed to focus on inter-individual differences of intelligence as part of their daily lives, or the be personally implied and concerned with them, as a result of their social insertions. Research has focused on parents and/or teachers as the social groups most preoccupied with the issue, often comparing their 
representations with those of other groups who should be less concerned with it (such as nonparents or students), due to their lower level of both direct experience and affective salience (Amaral, 1997; Carugati, et al., 1989; Carugati \& Selleri, 2004; Carugati, et al., 1994; Matteucci, 2007; Miguel, Valentim, \& Carugati, 2010; Mugny \& Carugati, 1985).

\section{Method}

\section{Hypotheses}

As suggested by the organizing principles approach to the study of social representations (Doise, 1992; Doise, et al., 1992) and supported by previous research (Molinari \& Speltini, 1998; Spini \& Doise, 1998; Wagner, Valencia, \& Elejabarrieta, 1996), the general hypothesis of the present study implies that subjects occupying different degrees of proximity to the object of representation will display different representational organizations. More specifically, the following hypotheses were advanced: the different categories of participants who present different degrees of proximity to the object, stemming from their several socioeducational positions - present different representations concerning the concept of intelligence $(\mathrm{H} 1)$, the development of intelligence $(\mathrm{H} 2)$ and the effectiveness of teaching procedures $(\mathrm{H} 3)$.

\section{Sample}

In the present study, a systematic sampling of contrasting populations was selected to test the hypotheses mentioned above. Following previous research (Amaral, 1997; Carugati, et al., 1989; Emiliani \& Molinari, 1994; Faria \& Fontaine, 1993; Molinari \& Speltini, 1998; Mugny \& Carugati, 1985; Raty, et al., 1993), participants were identified in terms of the direct experience and affective salience that intelligence was supposed to have for them, therefore 
grounding different levels of proximity to the object. The groups of participants in the study formed five distinct categories:

1) mothers of school-aged children - participants to whom intelligence is a relevant part of their everyday lives and constitutes a significant part of their identity, therefore presenting a very high degree of proximity and involvement to the object (high experience, high salience);

2) fathers of school-aged children - participants to whom intelligence is a relevant part of their everyday lives, but to whom, due to the dominant cultural models that attribute a historically preponderant social value to maternity (Poeschl, 2000), intelligence may not carry the same kind of implications and conflict as participants with a motherhood status (high experience, moderate salience);

3) mother-teachers - participants with a double educational role (as mothers and as teachers) and whose parental and professional identities imply a very high degree of proximity and affective involvement to matters relating to intelligence and its development (high experience, high salience);

4) psychology university students - childless men and women with no parental responsabilities in child education and development of intelligence but that, due to the course they are attending, may have some affective and conceptual involvement with the topics (low experience, moderate salience);

5) science univesity students - childless men and women with no parental responsabilities in child education and development of intelligence and to whom the object of intelligence may present a low salience (low experience, low salience).

The choice of this systematic sampling of contrasting populations with different socioeducational positions was based on the assumption that, as a result of their social insertions, different groups of individuals may present diverse degrees of proximity to the object of 
intelligence, which has been shown to modulate the content of representations (Amaral, Carugati, Peixoto, \& Selleri, 2006; Carugati, et al., 1989; Molinari \& Speltini, 1998; Mugny \& Carugati, 1985).

This study involved 752 Portuguese participants: 117 fathers, 227 mothers, 122 mother-teachers and 286 university students. Considering the whole sample, 550 participants were women (73\%) and 202 were men (27\%), ranging from 17 to 69 years old $(M=32.34, S D=$ 10.24).

Separately considered, fathers presented a mean age of $40.39(S D=5.76$; ages between 25 and 69 years old), mothers a mean of $37.73(S D=4.49$; ages between 24 and 48 years old) and mother-teachers a mean of $41.89(S D=6.41$; ages entre 29 e 60$)$. Concerning the university students, 182 of them attended a degree in Psychology and had an average age of 20.56 (SD = 1.75; ages between 19 and 29 years old). The remaining 104 students attended science courses (24 of them attended a Mathematics course and 78 were Civil Engineering students). For these participants, the average age is $21.0(S D=2.70$; ages between 17 and 34 years old).

\section{Procedure}

After verbal and written contact with school members explaining the general goal of the investigation and asking their cooperation, questionnaires were handled to children to be taken home to their parents. After being filled in, questionnaires were returned back to school, again via children. In order to increase the number of mother-teachers, some additional schools were contacted and requested to directly handle the questionnaire to teachers. As for students, university professors were asked to cooperate and allow the questionnaire to be filled in the context of their lectures. 
In the first page, participants were requested for their collaboration and assured of the purely scientific context and purpose of the research. The questionnaire was anonymous and confidentiality was also guaranteed. All instructions were in writing and sufficiently detailed to enable the participants to answer the questionnaire on their own. Nonetheless, since the majority of participants filled in the questionnaire at home, the investigator's email contact was left in case of need for any eventual misunderstanding of instructions. Since students were questioned with the investigator's presence, all doubts or questions were immediately answered.

Those who expressed a wish to be informed of the results of the research were assured to be later sent a report with the main conclusions. All schools who played an important contribution for data collection were guaranteed the same.

\section{Measures}

The questionnaire included a demographic profile sheet which asked for the participant's age and sex, occupation and academic qualification. When applicable, the number and age of children was also asked. The questionnaire itself consisted of three subquestionnaires, which we shall now detail.

\section{Questionnaire 1: Nature of intelligence}

A total of 42 items composed the questionnaire relating to the concept of intelligence. Subjects responded to each item by indicating the extent of agreement or disagreement on a seven-point scale $(1=$ totally disagree, $7=$ totally agree $)$. The items were formulated so as to represent a sufficiently broad spectrum of the views and positions previously identified in literature (Amaral, 1997; Amaral, et al., 2006; Carugati, et al., 1994; Faria \& Fontaine, 1993;

Matteucci, 2007; Mugny \& Carugati, 1985; Poeschl, 1998, 2001; Sternberg, 1985, 2004; 
Sternberg, Conway, Ketron, \& Bernstein, 1981), as well as in a preliminary phase of our research (Miguel, Valentim, \& Carugati, 2008; Miguel, et al., 2010). To present an overall idea, the main themes dealt with in this questionnaire were the following: heredity versus acquisition of intelligence (e.g., "gifted children are an example of the universally inborn character of intelligence"), adaptation to society (e.g., "intelligence is the individual's capacity to adapt to the society in which he lives"), cybernetic prototype of intelligence (e.g., "logic and mathematics are the prototypes of intelligence"), cognitive skills (e.g., "intelligence is gauged by the capacity of abstract thought"), unfamiliarity (e.g., "the existence of differences between individuals is a mysterious problem which science has been unable to solve"), teachers and failure (e.g., "failure is generally due to the teacher's lack of understanding of the child"), family inheritance (e.g., "intelligent children come from families where the parents value intelligence"), critical dimension (e.g., "being intelligent means agreeing to disagree with other people"), social skills (e.g., being intelligent means having good manners"), sociability (e.g., "being intelligent means being able to make friends"), social conformism (e.g., "being intelligent means conforming to the norms of a society"), integration of information (e.g., "an intelligent person is someone who is able to relate different subjects"), practical intelligence (e.g., "being intelligent means applying knowledge to new situations"), motivational factors (e.g., "the need to increase knowledge reveals a person's intelligence"), goal orientation (e.g., "being intelligent is having ambitions and being able to achieve them"), multiplicity of dimensions (e.g., "there is not only one way of being intelligent: there are several"), problem solving (e.g., "being intelligent is being able to solve problems"), learning (e.g., "intelligence is the capacity to learn from experience"), easiness (e.g., "intelligence is expressed by the easiness to perform certain tasks"), emotional intelligence (e.g., "being intelligent means being able to understand and adequately react to other people's emotions"), universality (e.g., "all people are intelligent in their own way") and cultural diversity (e.g., "even pupils that are unsuccessful in school can be intelligent in other domains"). A principal component analysis 
(PCA) was conducted on the 42 items with orthogonal rotation (varimax) and the five components retained by the scree plot were considered for the final analysis. In combination, these factors explained $44.7 \%$ of the variance (see Appendix 1 ). The first component - named social intelligence - accounts for a definition of intelligence as conformism to social norms and values, social adaptation, sociability and emotional regulation when in interaction with others, and explains $14.9 \%$ of the total variance. The items that cluster together in the second component - which explains $10.3 \%$ of variance - suggest that intelligence is an inner ability defined by higher cognitive processes, taking logical-mathematical reasoning as its prototype. For this reason, this component was named cybernetic prototype and natural inequalities. The third component - explaining $6.7 \%$ of variance - highlights the developmental potential of intelligence, defining it as an acquired capability and, therefore, a universal characteristic which all people can access. Therefore, it was named acquisition of intelligence. The fourth component, explaining $6.6 . \%$ of variance, emphasizes the idea that it is teachers that, through a set of essentially relational characteristics, are responsible for children's failure. For this reason, it was named teachers and failure. The fifth component - which explains $6.1 \%$ of the total variance - stresses the practical nature of intelligence, defining it as the ability of solving problems and integrating information.

\section{Questionnaire 2: Development of intelligence}

Subjects responded to the total of 31 items by indicating the extent of agreement or disagreement on a seven-point scale $(1=$ totally disagree, $7=$ totally agree $)$. As in the previous case, the process which led to the construction of the questionnaire on the development of intelligence was based, on the one hand, on literature review (Amaral, 1997; Constans \& Leonardis, 2003; Faria \& Fontaine, 1993; Flament, 1999; Matteucci, 2007; Mugny \& Carugati, 1985; Poeschl, 1998, 1999, 2001; Sternberg, 1985, 2004; Sternberg, et al., 1981) and, on the other, on preliminary results of our research (Miguel, Valentim \& Carugati, 2008, 2010). Once 
again, several themes were included: social determinism (e.g., "the family's cultural level affects the development of intelligence"), biological determinism (e.g., "intelligence does not develop, it is a hereditary gift"), parents' role (e.g., "the parents are the child's main model for the development of his own intelligence"), teachers' role (e.g., "teachers' competence is the best assurance of the child's development of intelligence"), peers' role (e.g., "have a group of children working together: they will develop their intelligence better than if they each work for themselves"), child control (e.g., "the child's intellectual progress depends on parental control and demands"), motivational factors (e.g., "ambitious children reveal greater intellectual progresses"), affection (e.g., "the development of intelligence requires a balanced affective development"), autonomy (e.g., "in order to develop his intelligence the child must be autonomous"), communication and dialogue (e.g., "for the child to develop her intelligence, it is necessary that she is able to establish a good communication with her colleagues and with adults"), social interaction (e.g., "interacting with other people is an essential element in the development of the child's intelligence"), discipline (e.g., "without rules and discipline, the development of intelligence is compromised"), didactic games and materials (e.g., "the use of didactic games and materials - for example, puzzles or paper-and-pencil activities - stimulates the child's intellectual development"), stimuli (e.g., "the development of intelligence is highly dependent on the stimuli and incentives given to the child") and challenging (e.g., "in order to progress, the child has to be challenged"). Principal component analysis retained three components which, in combination, explain $42.4 \%$ of variance (see Appendix 2). The first component, which explains $16.7 \%$ of the total variance, relates the development of intelligence to affective equilibrium and disciplinary practices, putting especial emphasis on a set of variables which relate to parent's role. In the second component the development of intelligence is seen as the result of a set of incentives and external motivational strategies that promote intellectual development. For this reason, this component, which accounts for $14.2 \%$ of the total variance, was named stimuli and incentives. As for the third component - school, 
teachers and molding - it is school and teachers who are emphasized, within a context of formal education, where severity and pressure on children are emphasized as major factors for their intellectual development. This factor accounts for $11.5 \%$ of variance.

Questionnaire 3: Effectiveness of teaching procedures

The third questionnaire was centered on teaching methods that participants judged appropriate for children who had consistent difficulties in certain academic areas and was composed of 19 items. Judgments about the relative effectiveness of the different educational solutions proposed were made on a seven-point scale ( $1=$ not effective; $7=$ totally effective $)$. Since all the dimensions identified in the preliminary phase of our research matched dimensions included in previous studies, all items used were from Mugny and Carugati's (1985) work. The teaching methods proposed covered an equally broad range of solutions, which we sum up to give an idea of the dimensions included in the questionnaire: motivation of the child (e.g., "help the child regain self-confidence"), reformulation (e.g., "make him do other problems of the same kind"), punishment (e.g., "give him a punishment"), extra homework (e.g., "give the child homework"), dialogue with parents (e.g., "talk to the parents about the child's difficulties"), repetition of correct models (e.g., "make him repeat the correct answer several times"), competition (e.g., "showing him that he is falling behind others"), work and peer-group relations (e.g., "make the child work in small groups"), laissez-faire attitude (e.g., "not to force him, things will come with time") and psychological diagnosis (e.g., "ask for the child to be given a psychological examination"). A principal component analysis was performed and the three component solution presented by the scree plot was considered. In combination, the three components explained $40.8 \%$ of variance (see Appendix 3). The first component, accounting for $18.4 \%$ of variance, stresses a set of variables which relate to the educators' role, suggesting that these agents should develop an emphatic relation with children in order to ensure a better climate in the classroom, encourage children and help 
them reformulate problems. Due to its content, this component was named support practices. In the second component, which explains $13.1 \%$ of the total variance, it is severe strategies that are emphasized: learning difficulties would be surpassed through the use of severe practices, centered on rewards and punishment, competition and extra homework. The third component accounts for $9.3 \%$ of variance and expresses the idea that the solution to children's difficulties should be left to time and professionals, therefore representing a sort of patient intervention.

\section{Results}

Nature of intelligence

As mentioned earlier, participants' age ranges from 17 to 69 years old. Given that the age span is quite large, the effect of this variable was considered necessary to be accounted for, in order to ensure that any differences in results were to be attributed to participants' category membership, independent of their age. Bearing this in mind, $\mathrm{H} 1$ was put to the test through a multivariate analysis of covariance (MANCOVA), which was conducted with the five components on the concept of intelligence as dependent variables, participants' category as the factor and age as the covariate. Using Pillai's trace, there was a significant effect of participants' category on their definitions of intelligence $[V=.150 ; F(20,2588)=5.04, p<.001]$, as well as a significant multivariate effect of age $[V=.032 ; F(5,644)=4.32, p<.001]$. Univariate analyses of each variable were then performed. As can be seen in Table 1, the univariate tests illustrated that there are category differences in social intelligence, teachers and failure and solving problems and integrating information. Participants' age presented a significant effect in acquisition of intelligence. 
Table 1. Nature of intelligence. Comparisons between categories of participants: means, standard-deviations and univariate tests

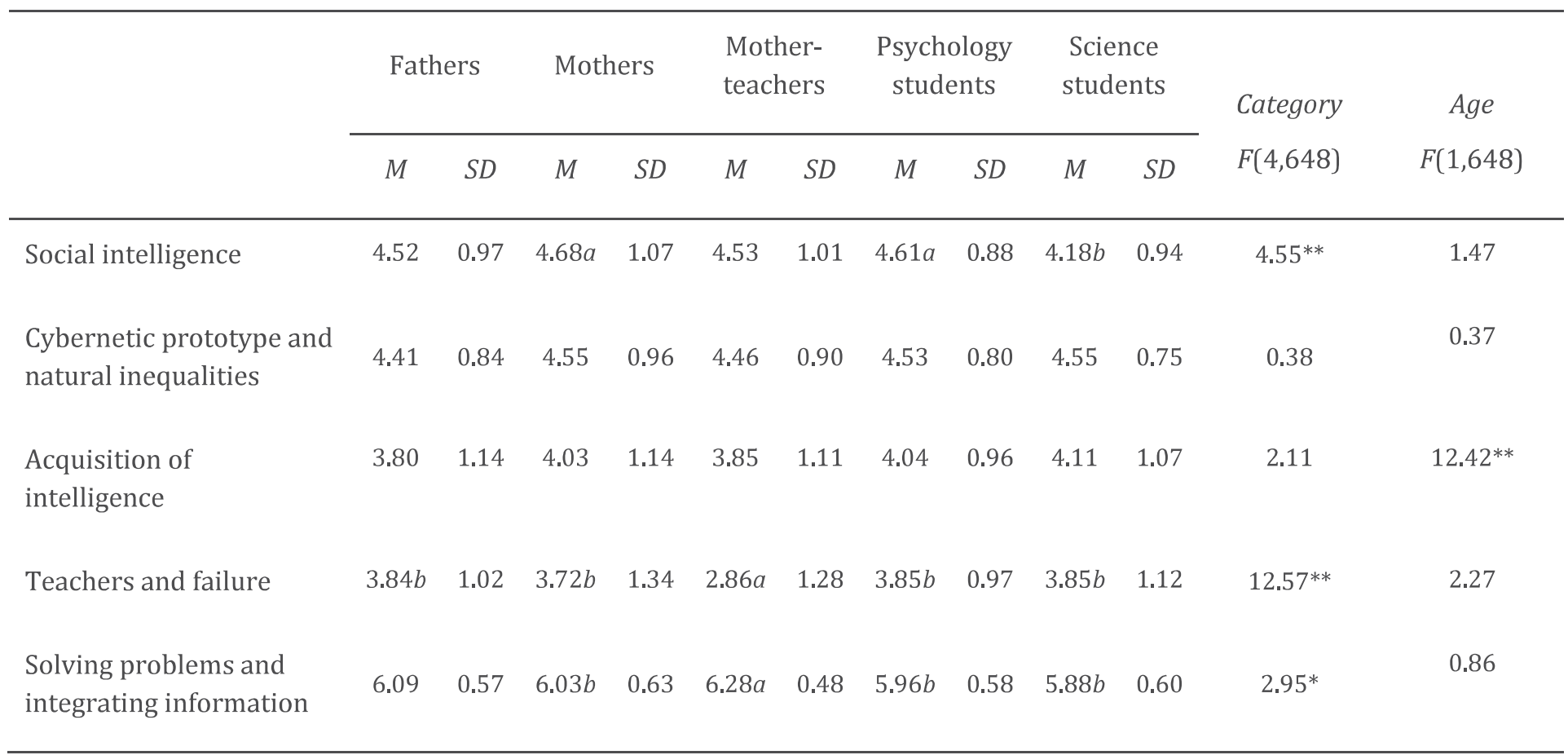

For each variable, the means which display different letters differ statistically between categories of participants, at $\alpha<.05$, according to Tukey post-hoc test.

${ }^{*} p<.05 ;{ }^{* *} p<.01$

Concerning the first factor, Tukey post-hoc tests show that the definition of intelligence as learning social rules, adapting to society and being sociable - social intelligence - is less relevant for science students than it is for mothers and psychology students. As for teachers and failure - which represents the attribution of academic failures to teachers' pedagogical skills - results show that this components is less stressed by mother-teachers, as they present a mean that is statistically lower than the rest of participants. However, it is mother-teachers who compared to the remaining participants privilege a definition of intelligence as the ability to solve problems and integrate information. Taken as a whole, results lend empirical support to $\mathrm{H} 1$ by showing that participants with different socioeducational positions differently privilege the several components concerning the definitions of intelligence. 
Development of intelligence

To test $\mathrm{H} 2$, another MANCOVA was performed, now taking the components concerning the development of intelligence as dependent variables and participants' category serving as factor, while age was introduced as covariate. Results showed that participants' category was found to be multivariate significant $(V=.075 ; F(12,2109)=4.51, p<.001)$. However, participants' age showed no significant multivariate effect $(V=.003 ; F(3,701)=0.68$, $p>.05)$, meaning that there is no significant adjustment of group means due to differences in age. As presented in Table 2, subsequent univariate tests for inter-category differences were significant for parents' role and stimuli and incentives.

Table 2. Development of intelligence. Comparisons between categories of participants: means, standard-deviations and univariate tests

\begin{tabular}{|c|c|c|c|c|c|c|c|c|c|c|c|c|}
\hline & \multicolumn{2}{|c|}{ Fathers } & \multicolumn{2}{|c|}{ Mothers } & \multicolumn{2}{|c|}{$\begin{array}{l}\text { Mother- } \\
\text { teachers }\end{array}$} & \multicolumn{2}{|c|}{$\begin{array}{l}\text { Psychology } \\
\text { students }\end{array}$} & \multicolumn{2}{|c|}{$\begin{array}{l}\text { Science } \\
\text { students }\end{array}$} & \multirow{2}{*}{$\begin{array}{l}\text { Category } \\
F(4,703)\end{array}$} & \multirow{2}{*}{$\begin{array}{c}\text { Age } \\
F(1,703)\end{array}$} \\
\hline & $M$ & $S D$ & $M$ & $S D$ & $M$ & $S D$ & $M$ & $S D$ & $M$ & $S D$ & & \\
\hline Parents' role & 5.27 & 0.72 & $5.40 a$ & 0.78 & $5.40 a$ & 0.88 & $5.09 b$ & 0.69 & $5.00 b$ & 0.88 & $2.86^{*}$ & 0.15 \\
\hline $\begin{array}{l}\text { Stimuli and } \\
\text { incentives }\end{array}$ & $6.14 b c$ & 0.43 & $6.20 b c$ & 0.48 & $6.33 c$ & 0.48 & $6.11 b$ & 0.59 & $5.82 a$ & 0.71 & $7.64^{* * *}$ & 0.03 \\
\hline $\begin{array}{l}\text { School, teachers } \\
\text { and molding }\end{array}$ & 4.61 & 0.76 & 4.57 & 0.96 & $4.35 a$ & 1.06 & $4.74 b$ & 0.68 & $4.85 b$ & 0.79 & $2.52^{*}$ & 1.96 \\
\hline
\end{tabular}

For each variable, the means which display different letters differ statistically between categories of participants, at $\alpha<.05$, according to Tukey post-hoc test.

${ }^{*} \mathrm{p}<.05$; $^{* * *} \mathrm{p}<.001$

Tukey post-hoc tests found significant differences between categories of participants for parents' role, showing that this components is more stressed out by mothers and motherteachers than by the students (both psychology and science). As for stimuli and incentives, results reveal that science students differ from the rest of the participants by emphasizing it less and that mother-teachers underline it more. Taken together, results lend empirical 
support to $\mathrm{H} 2$, showing that different dimensions concerning the representations of the development of intelligence are differently valued by the several categories of participants, independent of their age.

Effectiveness of teaching procedures

To assess the effects of participants' category on representations of the effectiveness of teaching procedures, another MANCOVA was performed, taking the components on the effectiveness of teaching procedures as dependent variables, participants' category as the fixed factor and age as covariate. The analysis resulted in a significant multivariate effect of participants' category $[\mathrm{V}=.120 ; F(12,2103)=7.31, p<.001]$. On the other hand, no multivariate effect of age was found $[\mathrm{V}=.009 ; F(3,699)=2.05, p>.05]$. As shown in Table 3, the univariate tests four inter-category differences found significant differences in all three components.

Table 3. Effectiveness of teaching procedures. Comparisons between categories of participants: means, standard-deviations and univariate tests

\begin{tabular}{|c|c|c|c|c|c|c|c|c|c|c|c|c|}
\hline & \multicolumn{2}{|c|}{ Fathers } & \multicolumn{2}{|c|}{ Mothers } & \multicolumn{2}{|c|}{$\begin{array}{l}\text { Mother- } \\
\text { teachers }\end{array}$} & \multicolumn{2}{|c|}{$\begin{array}{c}\text { Psychology } \\
\text { students }\end{array}$} & \multicolumn{2}{|c|}{$\begin{array}{l}\text { Science } \\
\text { students }\end{array}$} & \multirow{2}{*}{$\begin{array}{l}\text { Category } \\
F(4,701)\end{array}$} & \multirow{2}{*}{$\begin{array}{c}\text { Age } \\
F(1,701)\end{array}$} \\
\hline & $M$ & $S D$ & $M$ & $S D$ & $M$ & $S D$ & $M$ & $S D$ & $M$ & $S D$ & & \\
\hline $\begin{array}{l}\text { Support } \\
\text { practices }\end{array}$ & $5.88 b d$ & 0.53 & $6.04 b c$ & 0.53 & $6.12 c$ & 0.51 & $5.86 d$ & 0.54 & $5.67 a$ & 0.56 & $7.16^{* * *}$ & 0.23 \\
\hline $\begin{array}{l}\text { Severe } \\
\text { practices }\end{array}$ & $3.51 a$ & 0.92 & $3.42 a$ & 1.10 & $3.00 b$ & 1.07 & $3.40 a$ & 0.85 & $3.62 a$ & 0.97 & $5.24^{* * *}$ & 0.13 \\
\hline $\begin{array}{l}\text { Patient } \\
\text { intervention }\end{array}$ & $4.02 a$ & 0.95 & $4.41 b$ & 1.12 & $4.84 c$ & 1.01 & $4.29 a b$ & 1.03 & $4.00 a$ & 1.15 & $9.88^{* * *}$ & 4.86 \\
\hline
\end{tabular}

For each variable, the means which display different letters differ statistically between categories of participants, at $\alpha<.05$, according Tukey post-hoc test.

$* * * p<.001$ 
Results reported in Table 3 revealed that, for support practices, science students differ from the remaining categories of participants, as they perceive these strategies as less effective. Additionally, psychology students differ significantly from some other participants in the sense that they stress less this component than mother and mother-teachers, while valuing it more than science students. Another significant difference is found between fathers and mother-teachers as the latter outstand the effectiveness of support practices. Concerning severe practices, mother-teachers differ significantly from the remaining categories of participants, devaluing the effectiveness of these strategies. On the other hand, they seem to privilege strategies which focus on patient intervention, a component on which mothers also differ both from fathers and from science students, perceiving these strategies as more effective. Taken together, results lend empirical support to H3.

\section{Discussion}

The main goal of the present study was to explore how the degree of proximity to intelligence, deriving from different social positions, differently explains the effects of anchoring in the organization of social representations (Carugati, et al., 1989; Doise, et al., 1992; Molinari \& Speltini, 1998; Spini \& Doise, 1998). For this reason, participants with different degrees of proximity to intelligence - resulting from their different degrees of direct experience and affective salience, which derive from their varying responsibilities and integration in the socio-educational field - were included. Proximity to the object was operationalized as different social categories related to the issue of intelligence, therefore leading to the consideration of social anchoring of representations (Doise, 1992; Spini \& Doise, 1998): due to their professional role or to the daily experience of interindividual differences of intelligence, parents and teachers comprise the social categories more highly implied in the 
subject; in opposition, the distance that childless participants experience from educational implications and responsibilities award them less proximity to the matter of intelligence and its development (Mugny \& Carugati, 1985).

In general, the work that we have conducted allows to understand the role of the degree of proximity in the construction of social representations. More specifically, our results seem to confirm the pivotal role of direct experience and affective salience - originating from the different socio-educational insertions -, calling attention on the ways in which social groups generate representations which serve group purposes, namely the maintenance of a positive identity, has it seldom has been argued in the literature (Carugati, et al., 1989; Mugny \& Carugati, 1985). In fact, according to the hypotheses initially formulated, our results lend further support to the fact that different social positions channel the formation of specific representations, revealing a social anchoring (Spini \& Doise, 1998) in social groups. Degree of proximity to the object of representation, which varies across the different social categories considered in this study, seems therefore to introduce systematic variations in the weight social groups give to different dimensions underlying the structure of representations of intelligence and its development.

In the most prominent work in the area (Mugny \& Carugati, 1985), the maintenance of a positive self-esteem and of a satisfying social identity has been advanced as the principle for understanding the variability in representational contents. Results presented in this paper seem also to reinforce this perspective. In fact, the disagreement that mother-teachers reveal concerning teachers and failure - a component which relates academic failure to teachers' pedagogical skills - is consistent with results of previous studies (Amaral, 1997; Carugati \& Selleri, 2004; Faria \& Fontaine, 1993; Mugny \& Carugati, 1985). The devaluation also shown by mother-teachers concerning the importance of school, teachers and molding for the development of intelligence might be understood in the same vein. Due to their high appreciation of parents' role, it might be assumed that mothers and mother-teachers 
underline the importance of their own educational role in their children's development of intelligence. Taking the specific example of mother-teachers, if, on the one hand, results suggest a non responsibility of school and teachers (see Table 1), on the other hand the same does not happen when it is their parental role that is at stake (see Table 2). This result seems to be in line with previous studies (Amaral, 1997), which had also shown that, for teachers, the valorization of parents' role in the development of intelligence parallels a non responsibility of school and teachers, which, in situations of academic failure, allows them the maintenance of a positive self-esteem (Carugati, et al., 1994; Valentim, 1997).

In the specific case of mothers, the emphasis on parents' role seems to conflict with previous results of our research (Miguel, Valentim \& Carugati, 2008, 2010), according to which parents seemed to adopt a more playful view of their role in their children's development of intelligence and to attribute to school and teachers the responsibility for children's formal education, especially in teaching specific academic subjects. However, this is only an apparent contradiction, as the items that cluster in the component referring to parents' role convey a meaning associated with the quality of parent-child relations and disciplinary practices in the family arena. In this sense, the fact that mothers seem to delegate their children's formal education on school and teachers seems to find no correspondence in terms of their parental responsibility for children's discipline and monitoring.

In general, science students seem to adopt some of the elements which compose the "ideology of gift", initially identified by Mugny and Carugati (1985; see also Valentim, 1997). In fact, the devaluation of parents' role and of constant accompaniment for children's development of intelligence, the attribution of responsibility to school and teachers, the emphasis on an objective form of evaluation and the belief on the effectiveness of severe practices on children as well as the rejection of a social definition of intelligence seem to support a more "rigid" perspective of intelligence and its development. Psychology students, on the other hand, are more ambivalent, either agreeing more with science students - by 
devaluing parents' role in the development of intelligence and by stressing the importance of school and teachers to this process - or with mothers, as they also tend to privilege a definition of intelligence which highlights social dimensions and the ability to solve problems.

In a different vein, fathers seem to be the participants whose representations are the least clearly outlined: while the rest of the participants evidence a greater adherence or rejection to certain dimensions, fathers only evidence a median agreement with the topics at stake. These results might be better understood if we consider that their educational role does not allow them to distance themselves from the matters that relate to intelligence and its development, while however the proximity that they establish with the object of representation does not carry the same kind of implications and conflict showed by the subjects with a motherhood status (mothers and mother-teachers). In fact, if it is true that, as some studies have been reporting, the concept of fatherhood has been changing and that there is a greater involvement of fathers in their children's education (Pleck \& Masciadrelli, 2004; Tamis-LeMonda \& Cabrera, 2002), it is not untrue to state, historically speaking, that motherhood still has a more preponderant social value and that dominant cultural models still relate women to family context and childrearing (Poeschl, 2000; Silva \& Poeschl, 2001/2002).

This way, the privileged acceptance that mothers revealed concerning the social definition of intelligence - expressed in items that convey to the adaptation to social norms, conformism and social integration - might transmit the importance ascribed to their own role as a socialization agent and to the transmission of socially defined rules, associated to the belief of intelligence as a legacy of the family values system (Faria \& Fontaine, 1993).

The present study was based on the theoretical principle that, through the activation of social roles, the individual's proximity to the object of representation - taken as different degrees of relevance and implication of the object to a certain social group - define different social regulations, which intervene and shape the content of the representation (Molinari \& Speltini, 1998; Moliner \& Gutermann, 2004; Wagner, et al., 1996). Results in fact provide 
empirical support to this principle by showing that, in face of such an intense topic in terms of personal involvement and responsibility, the contradictory and ambivalent aspects of the social representation are managed through a regulative mechanism which links several elements of knowledge based on the affective value associated to the specific social object. Different levels of proximity to the representational object of intelligence may, in fact, impose different degrees of personal involvement in decision making and action taking concerning children's education and development of intelligence, as well as imply differing demands on the need to maintain a positive self-identity, which may entail psychosocial variables and mechanisms that explain the modulation of representations across social groups. Therefore, data also suggests that the structure of a given social representation is related to the instrumentality of knowledge (Jovchelovitch, 2007), reflecting the functional character that the organization of representations has on specific social dynamics. Additionally, it must be taken into account that social representations define the experience of reality and contribute to the maintenance of institutionalized relations, in a ideological framework that serves to maintain social order and defend particular identities (Howarth, 2006b). By showing that the content and organization of representations of intelligence are not independent of social positions and roles that social actors occupy in the social space, results highlight the importance of positional and dynamic ideologies (Doise, 1982, in press, 2011) in the construction of reality.

Nevertheless, we can underline some limits of this research. A first limit concerns the way in which individuals perceive and identify themselves as members of groups and their differentiated position with respect to other groups, as suggested by the theories of social identity (Tajfel \& Turner, 1986) and self-categorization (Turner, Hogg, Oakes, Reicher, \& Whetherell, 1987). Further studies should have to take into account and measure these processes. More specifically, in order to assess the degree of actual salience and involvement with the topic of intelligence, it might be of interest that future studies include a measure of identification with certain social categories and roles so as, in addition to considering objective 
social categories and studying sociological anchoring, psychosociological anchoring may also be regarded (Doise, 1992; Poeschl, 1998). Furthermore, this perspective would provide further theoretical elements to connect two fields of research - identity and social representations as suggested by Breakwell (1993) and more recently by Moloney (2010) and Moloney and Walker (2007). A second limit concerns the relationship between social representations and practices. In fact, representations are taken as guides for action (Abric, 1997b, 2001b; Jodelet, 1989; Moscovici, 1961), which direct behaviors and social relations. Therefore, future studies should try to explore how these representations of intelligence might influence behavior, namely educational and teaching practices in children's development (Matteucci, 2007; Mugny \& Carugati, 1985). In addition, and since identities do not have separate existences but are, instead, interacting entities, action decision may also be influenced by category memberships, especially when the object of representation is a puzzling and salient one. In the same vein as the contents of representations, differences in action taking may be, in fact, illustrated and explained by the different levels of experience towards the object of participants forming social categories (Abric, 2001a), which shape different levels of proximity to the object. The question of social representations in relation to different forms of action is still underdeveloped and offers promising prospects for research. Nevertheless its limits, we hope that this paper will contribute in one way or another to take into account the proximity to the object in the study of representations and to raise this factor to the interest it deserves. 


\section{References}

Abric, J.-C. (1997a). Les représentations sociales: Aspects théoriques. In J.-C. Abric (Ed.), Pratiques sociales et représentations (2nd ed., pp. 11-36). Paris: Presses Universitaires de France.

Abric, J.-C. (1997b). Pratiques sociales, représentations sociales. In J.-C. Abric (Ed.), Pratiques sociales et représentations (2nd ed., pp. 217-238). Paris: Presses Universitaires de France.

Abric, J.-C. (2001a). L'approche structurale des représentations sociales: Développements récents. Psychologie et Société, 4(2), 81-104.

Abric, J.-C. (2001b). A structural approach to social representations. In K. Deaux \& G. Philogène (Eds.), Representations of the social: Bridging theoretical traditions (pp. 42-47). Oxford: Blackwell.

Amaral, V. (1997). A inteligência e o seu desenvolvimento: Representações sociais e identidades sociais. In M. B. Monteiro \& P. Castro (Eds.), Cada cabeça sua sentença: Ideias dos adultos sobre as crianças (pp. 33-74). Oeiras: Celta.

Amaral, V., Carugati, F., Peixoto, F., \& Selleri, P. (2006). Representações sociais como princípios organizadores de conteúdos cognitivos: Um estudo sobre as representações sociais da inteligência. Actas do VI Simpósio Nacional de Investigação em Psicologia (pp. 100-109). Évora: Universidade de Évora.

Augoustinos, M., Walker, I., \& Donaghue, N. (2006). Social cognition: An integrated introduction (2nd ed.). London: Sage.

Breakwell, G. M. (1993). Social representations and social identity. Papers on Social Representations, 2(3), 1-20.

Carugati, F. (1990a). Everyday ideas, theoretical models and social representations: The case of intelligence and its development. In G. R. Semin \& K. J. Gergen (Eds.), Everyday understanding: Social and scientific implications (pp. 130-150). London: Sage Publications.

Carugati, F. (1990b). From social cognition to social representations in the study of intelligence. In G. Duveen \& B. Lloyd (Eds.), Social representations and the development of knowledge (pp. 126143). Cambridge: Cambridge University Press.

Carugati, F., Emiliani, F., \& Molinari, L. (1989). Being a mother is not enough: Theories and images in social representations of childhood. Revue Internationale de Psychologie Sociale, 3(3), 289-306.

Carugati, F., \& Selleri, P. (2004). Intelligence, educational practices and school reform: Organisations change, representations persist. European Journal of School Psychology, 2, 149-167.

Carugati, F., Selleri, P., \& Scappini, E. (1994). Are social representations an architecture of cognitions? A tentative model for extending the dialog. Papers on Social Representations, 3(2), 134-151.

Castro, P. (2006). Applying social psychology to the study of environmental concern and environmental worldviews: Contributions from the social representations approach. Journal of Community and Applied Social Psychology, 16, 247-266.

Clémence, A. (2001). Social positioning and social representations. In K. Deaux \& G. Philogène (Eds.), Representations of the social: Bridging theoretical traditions (pp. 83-95). Oxford: Blackwell. 
Constans, S., \& Leonardis, M. (2003). Co-construction of the representations of intelligence between mother and daughter: Developmental and differential approaches. European Journal of Psychology of Education, 18(4), 369-387.

Dany, L., \& Abric, J.-C. (2007). Distance à l'objet et représentations du cannabis. Revue Internationale de Psychologie Sociale, 20(3), 77-104.

Doise, W. (1982). L'explication en psychologie sociale. Paris: Presse Universitaire de France.

Doise, W. (1985). Les représentations sociales: Définition d'un concept. Connexions, 45, 243-253.

Doise, W. (1990). Les représentations sociales. In R. Ghiglione, C. Bonnet \& J.-F. Richard (Eds.), Traité de psychologie cognitive: Cognition, représentation, communication (pp. 111-174). Paris: Dunod.

Doise, W. (1992). L'ancrage dans les études sur les représentations sociales. Bulletin de Psychologie, 45(405), 189-195.

Doise, W. (1993). Debating social representations. In G. M. Breakwell \& D. V. Canter (Eds.), Empirical approaches to social representations (pp. 157-170). Oxford: Clarendon.

Doise, W. (in press, 2011). The homecoming of society in social psychology. In J. P. Valentim (Ed.), Societal approaches in social psychology. Berne: Peter Lang.

Doise, W., Clémence, A., \& Lorenzi-Cioldi, F. (1992). Représentations sociales et analyses de données. Grenoble: Presses Universitaires de Grenoble.

Eagly, A. H., \& Chaiken, S. (1993). The psychology of attitudes. Fort North, Ph: Harcourt Brace Jovanovich.

Emiliani, F., \& Molinari, L. (1994). From the child to one's own child: Social dynamics and identities at work. European Journal of Social Psychology, 24, 303-316.

Faria, L., \& Fontaine, A. M. (1993). Representações dos professores sobre a natureza e desenvolvimento da inteligência. Revista Portuguesa de Pedagogia, 3, 471-487.

Fishbein, M., \& Ajzen, I. (1975). Belief, attitude, intention and behavior: An introduction to theory and research. Reading, MA: Addison-Wesley.

Flament, C. (1999). Liberté d'opinion et limite normative dans une représentation sociale: Le développement de l'intelligence. Swiss Journal of Psychology, 58(3), 201-206.

Gruev-Vintila, A., \& Rouquette, M. L. (2007). Social thinking about collective risk: How do risk-related practice and personal involvement impact its social representations? Journal of Risk Research, 10(4), 555-581.

Gurrieri, C., Wolter, R. P., \& Sorribas, E. (2007). Límplication personnelle: Un outil psychosocial pour comprendere le lien population-objet. Psicologia em Estudo, 12(2), 423-432.

Howarth, C. (2006a). How social representations of attitudes have informed attitude theories: The consensual and the reified. Theory and Psychology, 16(5), 691-714.

Howarth, C. (2006b). A social representations is not a quiet thing: Exploring the critical potential of social representations theory. British Journal of Social Psychology, 45, 65-86.

Jodelet, D. (1989). Folies et représentations sociales. Paris: PUF. 
Jovchelovitch, S. (2007). Knowledge in context: Representations, community and culture. Hove, East Sussex: Routledge.

Jovchelovitch, S. (2008). The rehabilitation on common sense: Social representations, science and cognitive polyphasia. Journal for the Theory of Social Behaviour, 38(4), 431-448.

Lo Monaco, G., \& Guimelli , C. (2008). Représentations sociales, pratique de consommation et niveau de connaissance: Le cas du vin. Les Cahiers Internationaux de Psychologie Sociale, 78, 35-50.

Matteucci, M. C. (2007). Teachers facing the school failure: The social valorization of effort in the school context. Social Psychology of Education, 10, 29-53.

McGillicuddy-De Lisi, A. V., \& Sigel, I. E. (1995). Parental beliefs. In M. H. Bornstein (Ed.), Handbook of parenting. Status and social conditions of parenting (Vol. 3, pp. 333-358). Mahwah, NJ: Lawrence Erlbaum Associates.

Miguel, I., Valentim, J. P., \& Carugati, F. (2008). Representações sociais da inteligência e práticas educativas: Apresentação de uma investigação em curso. In A. Caetano, M. Garrido, S. Batel \& A. M. Martins (Eds.), Percursos da investigação em psicologia social e organizacional (Vol. III, pp. 301-318). Lisboa: Edições Colibri.

Miguel, I., Valentim, J. P., \& Carugati, F. (2009). Parental ideas and their role in childrearing: The ideabehavior connection. Italian Journal of Sociology of Education, 3, 225-253.

Miguel, I., Valentim, J. P., \& Carugati, F. (2010). Intelligence and its development: Social representations and social identities. Papers on Social Representations, 19, 20.21-20.33.

Molinari, L., \& Speltini, G. (1998). Breast feeding, practices and values: A study of social representations. Swiss Journal of Psychology, 57(4), 235-247.

Moliner, P., \& Gutermann, M. (2004). Dynamique des descriptions et des explications dans une représentation sociale. Papers on Social Representations, 13, 2.1-2.12.

Moloney, G. (2010). Acknowledging Gerard. Articulating social representations and identity through process and content: The resettlement of refugees in regional Australia. Papers on Social Representations, 19, 15.11-15.16.

Moloney, G., \& Walker, I. (2007). Social representations and identity: Content, process and power. New York, NY: Palgrave Macmillan.

Moscovici, S. (1961). La psychanalyse, son image et son publique. Paris: PUF.

Moscovici, S. (1981). On social representations. In J. P. Forgas (Ed.), Social cognition: Perspectives on everyday understanding (pp. 181-209). London: Academic Press.

Moscovici, S., \& Hewstone, M. (1984). De la science au sense commun. In S. Moscovici (Ed.), Psychologie sociale (pp. 539-566). Paris: PUF.

Moscovici, S., \& Marková, I. (2000). Ideas and their development: A dialogue between Serge Moscovici and Ivana Marková. In G. Duveen (Ed.), Social representations: Explorations in social psychology (pp. 224-286). Cambridge: Polity Press.

Mugny, G., \& Carugati, F. (1985). L'Intelligence au pluriel: Les représentations sociales de l'intelligence et de son développement. Cousset: Editions DelVal.

Petty, R. E., Fazio, R. H., \& Briñol, P. (2009). Attitudes: Insights from the new implicit measures. New York: Psychology Press. 
Pleck, J. H., \& Masciadrelli, B. P. (2004). Paternal involvement: Levels, sources and consequences. In M. E. Lamb (Ed.), The role of the father in child development (4th ed., pp. 222-273). New York: Wiley.

Poeschl, G. (1998). Processus d'ancrage et représentations sociales de l'intelligence. Psicologia, 12, 85100.

Poeschl, G. (1999). Intelligence masculine et intelligence féminine. In B. Bril, P. Dasen, C. Sabatier \& B. Krewer (Eds.), Propos sur l'enfant et l'adolescent: Quels enfants por quelles cultures? (pp. 297315). Paris: L'Harmattan.

Poeschl, G. (2000). Trabalho doméstico e poder familiar: Práticas, normas e ideais. Análise Social, 15, 695-719.

Poeschl, G. (2001). Social comparison and differentiation strategies in social representations of intelligence. Swiss Journal of Psychology, 60(1), 15-26.

Räty, H., \& Snellman, L. (1995). On the social fabric of intelligence. Papers on Social Representations, 4(2), 177-185.

Räty, H., Snellman, L., \& Vornanen, A. (1993). Public views on intelligence: A Finnish study. Psychological Reports, 72, 59-65.

Salesses, L. (2005a). Effet d'attitude dans le processus de structuration d'une représentation sociale. Psychologie Française, 50, 471-485.

Salesses, L. (2005b). Rôle du niveau de connaissance dans le processus de structuration d'une représentation sociale. Les Cahiers Internationaux de Psychologie Sociale, 66, 25-42.

Sigel, I. E. (1985). A conceptual analysis of beliefs. In I. E. Sigel (Ed.), Parental belief systems: The psychological consequences for children (pp. 345-371). Hillsdale, NJ: Erlbaum.

Silva, A., \& Poeschl, G. (2001/2002). Representações das semelhanças e das diferenças entre os sexos. Cadernos de Consulta Psicológica, 17-18, 153-159.

Spini, D., \& Doise, W. (1998). Organizing principles of involvement in human rights and their social anchoring in value priorities. European Journal of Social Psychology, 28, 603-622.

Sternberg, R. J. (1985). Implicit theories of intelligence, creativity and wisdom. American Psychologist, 49(3), 607-627.

Sternberg, R. J. (2004). Culture and intelligence. American Psychologist, 59(5), 325-338.

Sternberg, R. J., Conway, B. E., Ketron, J. L., \& Bernstein, M. (1981). People's conceptions of intelligence. Journal of Personality and Social Psychology, 41, 37-55.

Tajfel, H., \& Turner, J. C. (1986). The social identity theory of intergroup behavior. In S. Worchel \& W. G. Austin (Eds.), Psychology of intergroup relations. Chicago, IL: Nelson-Hall.

Tamis-LeMonda, C., \& Cabrera, N. (Eds.). (2002). Handbook of father involvement. Mahwah, NJ: Lawrence Erlbaum Associates.

Turner, J. C., Hogg, M., Oakes, P. J., Reicher, S., \& Whetherell, M. S. (1987). Rediscovering the social group: A self-categorization theory. Oxford: Blackwell.

Valentim, J. P. (1997). Escola, igualdade e diferença. Porto: Campo das Letras. 
Voelklein, C., \& Howarth, C. (2005). A review of controversies about social representations theory: A british debate. Culture and Psychology, 11(4), 431-454.

Wagner, W., Valencia, J., \& Elejabarrieta, F. (1996). Relevance, discourse and the "hot" stable core of social representations: A structural analysis of word association. British Journal of Social Psychology, 35, 331-351. 
Nature of intelligence: Results of the principal component analysis after Varimax rotation

\begin{tabular}{|c|c|c|c|c|c|c|c|}
\hline \multirow{2}{*}{ Items } & \multirow{2}{*}{$M$} & \multirow{2}{*}{$S D$} & \multicolumn{5}{|c|}{ Factors } \\
\hline & & & 1 & 2 & 3 & 4 & 5 \\
\hline $\begin{array}{l}\text { Being intelligent means being able to establish relationships with } \\
\text { other people }\end{array}$ & 4.52 & 1.49 & .798 & .074 & .090 & .080 & .027 \\
\hline Being intelligent means being able to make friends & 4.13 & 1.64 & .706 & .050 & .101 & -.022 & .058 \\
\hline Being intelligent means having good manners & 3.83 & 1.70 & .699 & .202 & .225 & -.008 & -.075 \\
\hline $\begin{array}{l}\text { Intelligence is the individual's capacity to adapt to the society in } \\
\text { which he lives }\end{array}$ & 4.84 & 1.45 & .691 & .027 & .002 & .081 & .191 \\
\hline Being intelligent means adopting rules of social interaction & 4.71 & 1.41 & .640 & .081 & .187 & .062 & .139 \\
\hline $\begin{array}{l}\text { Being intelligent means understanding and adequately reacting to } \\
\text { other peoples' emotions }\end{array}$ & 5.24 & 1.31 & .627 & -.037 & .048 & .083 & .226 \\
\hline Being intelligent is having ambitions and being able to achieve them & 4.81 & 1.47 & .626 & .203 & -.022 & .106 & .018 \\
\hline Intelligence means managing to involve other people in conversation & 4.26 & 1.53 & .484 & .325 & -.096 & .167 & .009 \\
\hline Being intelligent means conforming to the norms of a society & 4.37 & 1.72 & .447 & .149 & .076 & .133 & .019 \\
\hline $\begin{array}{l}\text { Being intelligent means behaving within the fundamental social } \\
\text { values of society }\end{array}$ & 4.80 & 1.51 & .445 & .303 & .254 & -.054 & -.024 \\
\hline Intelligent people have good memory skills & 4.72 & 1.46 & .050 & .603 & -.032 & .088 & .077 \\
\hline Logics and mathematics are the prototypes of intelligence & 4.54 & 1.61 & -.002 & .597 & .085 & .004 & .099 \\
\hline Intelligence is expressed in quickness of performance & 4.05 & 1.66 & .128 & .547 & .310 & .053 & .010 \\
\hline $\begin{array}{l}\text { Gifted children are an example of the universally inborn character of } \\
\text { intelligence }\end{array}$ & 4.54 & 1.60 & .020 & .533 & -.023 & .100 & .050 \\
\hline $\begin{array}{l}\text { Being intelligent means having a unique and general ability to } \\
\text { perform well }\end{array}$ & 4.59 & 1.63 & .200 & .532 & -.071 & .112 & .015 \\
\hline The computer is the perfect model of what intelligence is & 3.48 & 1.78 & .050 & .517 & .185 & .029 & -.155 \\
\hline Intelligence is expressed by the easiness to perform certain tasks & 4.62 & 1.60 & .197 & .474 & .265 & -.016 & -.012 \\
\hline Intelligent people have good language skills & 4.72 & 1.50 & .280 & .452 & -.127 & -.042 & .222 \\
\hline Intelligence is the capacity to learn whatever you are taught & 5.37 & 1.17 & .185 & .414 & .134 & .044 & .115 \\
\hline People are not born intelligent: they learn how to become intelligent & 4.53 & 1.59 & .145 & -.066 & .671 & -.035 & .051 \\
\hline Intelligence is gauged by the capacity for concentration & 4.27 & 1.61 & .076 & .218 & .609 & .023 & .177 \\
\hline $\begin{array}{l}\text { An intelligent person is someone who has strongly developed a } \\
\text { specific skill }\end{array}$ & 3.75 & 1.67 & .031 & .320 & .581 & .214 & -.002 \\
\hline Everyone is intelligent in their own way & 3.38 & 1.75 & .226 & -.029 & .477 & .245 & -.197 \\
\hline $\begin{array}{l}\text { Failure could generally be avoided, given more patience on the part of } \\
\text { the teacher }\end{array}$ & 4.28 & 1.63 & .002 & .052 & .131 & .784 & .126 \\
\hline $\begin{array}{l}\text { Failure is generally due to the teacher's lack of understanding of the } \\
\text { child }\end{array}$ & 3.22 & 1.47 & .153 & .116 & .079 & .774 & -.073 \\
\hline $\begin{array}{l}\text { Children's behavior problems are due to the teacher's lack of severity } \\
\text { and discipline }\end{array}$ & 3.49 & 1.53 & .205 & .141 & .011 & .691 & -.030 \\
\hline Being intelligent means applying knowledge to new situations & 6.14 & 0.77 & .161 & .089 & -.073 & -.040 & .790 \\
\hline $\begin{array}{l}\text { Being intelligent means being able to develop adequate strategies of } \\
\text { problem solving }\end{array}$ & 6.29 & 0.71 & .176 & .048 & .002 & .044 & .775 \\
\hline Intelligence is the capacity to relate different subjects altogether & 5.63 & 1.13 & .035 & .109 & .292 & .012 & .467 \\
\hline Variance accounted for (total $=44.65 \%$ ) & & & 14.9 & 10.3 & 6.7 & 6.6 & 6.1 \\
\hline
\end{tabular}




\section{Appendix 2}

Development of intelligence: Results of the principal component analysis after Varimax rotation

\begin{tabular}{|c|c|c|c|c|c|}
\hline \multirow{2}{*}{ Items } & \multirow{2}{*}{$M$} & \multirow{2}{*}{$S D$} & \multicolumn{3}{|c|}{ Factors } \\
\hline & & & 1 & 2 & 3 \\
\hline $\begin{array}{l}\text { For the child to develop her intelligence, it is fundamental to dialogue with her } \\
\text { about her behaviors }\end{array}$ & 5.50 & 1.11 & .675 & .174 & .109 \\
\hline $\begin{array}{l}\text { The quality of affective relations between parents and children influences the } \\
\text { development of intelligence }\end{array}$ & 5.71 & 1.14 & .645 & .254 & -.053 \\
\hline $\begin{array}{l}\text { For the child to develop her intelligence, it is necessary that parents keep up } \\
\text { with all her activities }\end{array}$ & 4.66 & 1.53 & .620 & -.036 & .235 \\
\hline $\begin{array}{l}\text { For the child to develop her intelligence, it is necessary that she is able to } \\
\text { establish a good communication with her colleagues and with adults }\end{array}$ & 5.40 & 1.14 & .612 & .225 & .150 \\
\hline $\begin{array}{l}\text { The child's intellectual development is influenced by the conscious that } \\
\text { parents have on appropriate studying schedule }\end{array}$ & 4.91 & 1.41 & .597 & .109 & .201 \\
\hline Without rules and discipline, the development of intelligence is compromised & 5.56 & 1.17 & .568 & .333 & .042 \\
\hline $\begin{array}{l}\text { A permissive family environment compromises the development of } \\
\text { intelligence }\end{array}$ & 4.76 & 1.43 & .546 & -.046 & .131 \\
\hline $\begin{array}{l}\text { Parents' interest and support to the child's schooling affects her intellectual } \\
\text { development }\end{array}$ & 5.46 & 1.30 & .474 & .256 & .125 \\
\hline $\begin{array}{l}\text { For the child to make progress, she has to be presented with challenges that } \\
\text { stimulate her intellectually }\end{array}$ & 6.24 & 0.70 & .060 & .790 & .077 \\
\hline $\begin{array}{l}\text { The development of intelligence is highly dependent on the stimuli and } \\
\text { incentives given to the child }\end{array}$ & 6.15 & 0.89 & .181 & .715 & -.084 \\
\hline $\begin{array}{l}\text { It is by questioning and stimulating the child's reasoning that the development } \\
\text { of intelligence can be promoted }\end{array}$ & 6.06 & 0.73 & .157 & .666 & .184 \\
\hline $\begin{array}{l}\text { The use of didactic games and materials - for example, puzzles or paper-and- } \\
\text { pencil activities - stimulates the child's intellectual development }\end{array}$ & 6.22 & 0.73 & .119 & .656 & .104 \\
\hline $\begin{array}{l}\text { For the child to progress intellectually, it is essential to stimulate the } \\
\text { development of reading habits }\end{array}$ & 6.01 & 0.92 & .378 & .505 & .028 \\
\hline School is the main responsible for the development of intelligence & 4.42 & 1.56 & -.057 & .086 & .721 \\
\hline $\begin{array}{l}\text { It is by contradicting the child when she is wrong that the development of } \\
\text { intelligence is promoted }\end{array}$ & 4.06 & 1.65 & .073 & -.044 & .577 \\
\hline For the child to make progress, it is necessary to present her the right answer & 4.53 & 1.55 & .174 & .023 & .569 \\
\hline $\begin{array}{l}\text { Teachers' competence is the best assurance of the child's development of } \\
\text { intelligence }\end{array}$ & 4.47 & 1.46 & .208 & .061 & .552 \\
\hline Ambitious children reveal greater intellectual progresses & 4.91 & 1.36 & .154 & .058 & .545 \\
\hline $\begin{array}{l}\text { Children with access to a wide variety of extracurricular activities have higher } \\
\text { possibilities of developing their intelligence }\end{array}$ & 5.32 & 1.29 & .113 & .280 & .419 \\
\hline Variance accounted for (total $=42.4 \%$ ) & & & 16.7 & 14.2 & 11.5 \\
\hline
\end{tabular}


Appendix 3

Effectiveness of teaching procedures: Results of the principal component analysis after Varimax rotation

\begin{tabular}{|c|c|c|c|c|c|}
\hline \multirow{2}{*}{ Items } & \multirow{2}{*}{$M$} & \multirow{2}{*}{$S D$} & \multicolumn{3}{|c|}{ Factors } \\
\hline & & & 1 & 2 & 3 \\
\hline Help the child regain self-confidence & 6.43 & 0.75 & .689 & -.111 & .035 \\
\hline Check that he really understands the data of the problem & 6.21 & 0.84 & .675 & -.182 & -.076 \\
\hline Use more stimulating methods & 6.28 & 0.78 & .673 &.-046 & .120 \\
\hline Practice different problems which will help him find the right answer & 5.93 & 0.95 & .601 & .020 & .083 \\
\hline Improve the classroom atmosphere & 5.78 & 1.02 & .552 & .095 & .075 \\
\hline Talk to parents about the child's difficulties & 5.88 & 1.10 & .519 & .012 & .217 \\
\hline Make the child work in small groups & 5.41 & 1.11 & .489 & .172 & .294 \\
\hline Teach him to be rigorous in his work & 5.75 & 1.08 & .481 & .394 & -.237 \\
\hline Pay an individual attention to the child & 5.66 & 1.22 & .446 & .063 & .240 \\
\hline Make him compete with other children & 3.58 & 1.66 & -.021 & .717 & -.016 \\
\hline Show him that he is falling behind the others & 3.26 & 1.58 & .037 & .625 & -.176 \\
\hline Give the child homework & 4.07 & 1.50 & .042 & .612 & .095 \\
\hline Give him a punishment & 2.00 & 1.37 & -.152 & .604 & .089 \\
\hline Promise him a reward if he does better & 4.02 & 1.67 & .099 & .577 & .277 \\
\hline Ask for the child to be given a psychological examination & 4.49 & 1.59 & .205 & -.013 & .697 \\
\hline Not to force him, things will come with time & 4.02 & 1.61 & -.027 & .052 & .681 \\
\hline Present him easier problems which he can solve & 4.48 & 1.52 & .259 & .056 & .480 \\
\hline Variance accounted for (total $=40.8 \%$ ) & & & 18.4 & 13.1 & 9.3 \\
\hline
\end{tabular}

